\title{
PENGARUH WAKTU PENCELUPAN PROSES ELECTROLESS PLATING TERHADAP PEMBENTUKAN LAPISAN TEMBAGA ANTIBAKTERI
}

\author{
Yudha Pratesa ${ }^{1}$, Luthfi Noviardi ${ }^{2}$, Muhammad Fadlilah ${ }^{2}$, Adimas Habib lqbal ${ }^{2}$, \\ dan Vika Rizkia ${ }^{3}$ \\ 1) Research Center of Biomedical Engineering, Fakultas Teknik, Universitas Indonesia, Kampus Baru \\ UI, Depok, 16424, Indonesia \\ ${ }^{2)}$ Departemen Teknik Metalurgi dan Material, Universitas Indonesia, Kampus Baru UI, Depok, 16424, \\ Indonesia \\ 3) Jurusan Teknik Mesin, Politeknik Negeri Jakarta, Depok, 16424, Indonesia \\ E-mail: yudha@metal.ui.ac.id
}

Received: 16 Januari 2018; revised: 26 Januari 2018; accepted: 2 April 2018

\begin{abstract}
ABSTRAK
PENGARUH WAKTU PENCELUPAN PROSES ELECTROLESS PLATING TERHADAP PEMBENTUKAN LAPISAN TEMBAGA ANTIBAKTERI. Penyebaran penyakit oleh bakteri sangat rentan menjadi wabah di rumah sakit dan fasilitas umum melalui kontak secara langsung dan tidak langsung. Kontak secara tidak langsung terjadi melalui alat perantara seperti jarum suntik, pakaian hingga gagang pintu. Salah satu bagian yang paling sering disentuh orang adalah gagang pintu dan kusen. Saat ini, banyak kusen yang dibuat dari bahan dasar logam aluminium karena harga yang murah, tahan korosi dan ringan. Kusen aluminium umumnya diproses anodisasi untuk memberikan efek warna karena kesukarannya jika dicat secara langsung. Produk anodisasi umumnya berstruktur pori sehingga dapat menjadi tempat ideal tumbuh dan berkoloni bakteri dengan mudah. Pada penelitian dilakukan pembuatan lapisan tembaga yang menutup pori dan mampu memberikan efek racun pada bakteri Escherichia Coli penyebab berbagai macam penyakit. Hasil dari penelitian ini menunjukkan, waktu electroless plating optimal selama 26 menit yaitu ketebalan antara 8-24 $\mu \mathrm{m}$. Tembaga berhasil melapisi permukaan material secara merata. Hasil pengujian antibakteri dengan Kirby test menunjukan hasil plating memiliki kemampuan untuk mencegah pertumbuhan bakteri. Hasil uji ketahanan lapisan terhadap cuaca menggunakan saltspray menunjukan pelapisan selama 26 menit memberikan efek yang terbaik.
\end{abstract}

Kata kunci : Antibakteri, Electroless plating, Eschericia coli

\begin{abstract}
EFFECT OF IMMERSION TIME ON ANTIBACTERIAL COPPER LAYER FORMATION DURING ELECTROLESS PLATING. A disease caused by bacteria is vulnerable to become an outbreak at hospitals and public facilities through direct and indirect contact. Indirect contact usually occurs through an intermediate medium such as syringes, clothing, and doorknob in the hospital. Doorknob and sills are the places where every people will touch during visitation in the hospitals. Currently, sills are preferably chosen from aluminum because of its low price, corrosion resistant and lightweight properties. Aluminum sill is usually anodized by anodizing process to give its color as it is hard to be coated directly. However, anodizing products will form porous on the surface, and hence it will make an ideal place for bacteria to grow and colonize. In this research, copper sealing was made to close the pores and give a toxic environment for Escherichia coli. Escherichia coli was selected as the target because it can cause several diseases. The result showed that optimal electroless plating time is 26 minutes with coating thickness between 8-24 $\mu$ m. Copper successfully sealed the surface pores evenly. Kirby test revealed antibiotic activity of copper layer in every variable of fabrication. Salt spray result also showed that 26 minutes plating time produced the best effect for long-term environmental resistance.
\end{abstract}

Keywords: Antibacterial, Electroless plating, Eschericia coli

\section{PENDAHULUAN}

Penyebaran penyakit oleh bakteri saat ini sangat rentan terjadi. Salah satu bakteri yang membawa penyakit adalah Escherichia coli. Penyebaran bakteri dapat terjadi secara langsung dan tidak langsung. Penyebaran secara tidak langsung umumnya melalui suatu media. Ketika orang yang sakit menyentuh sebuah media, ada kemungkinan bakteri 
tersebut ikut menempel bersama dengan cairan tubuh yang ada pada material tersebut. Penularan seperti ini banyak terjadi di fasilitas umum seperti rumah sakit, stasiun atau pusat perbelanjaan. Salah satu peralatan yang bisa menjadi media perpindahan bakteri adalah kusen, pajangan dan gagang pintu.

Saat ini logam aluminium banyak digunakan sebagai bahan untuk pengganti kayu pada aplikasi kusen di berbagai bangunan. Aluminium dipilih karena sifatnya yang ringan, murah dan tahan terhadap korosi.

Berbeda dengan kayu, alumunium sulit untuk langsung dicat sehingga harus dilakukan proses pewarnaan dengan anodisasi menggunakan larutan pewarna untuk mendapatkan warna yang diinginkan sekaligus ketahanan korosi yang baik. Contoh dari aplikasi ini adalah pembuatan gagang pintu. Namun, akibat dari proses anodisasi permukaan aluminum akan berpori dan permukaan yang berpori dapat menjadi kondisi yang ideal untuk bakteri tumbuh dan melekat.

Hasil pengamatan proses pembuatan makanan berbahan dasar ayam menunjukan material baja tahan karat yang dilakukan proses rekayasa permukaan dengan poles listrik menghasilkan permukaan yang halus dan membuat jumlah bakteri yang tumbuh sedikit (Arnold dan Bailey 2000). Kondisi yang sama juga ditemukan dalam aplikasi kedokteran gigi yaitu semakin kasar permukaan implant penambal gigi akan semakin mudah proses adhesi bakteri di tempat tersebut (Aykent et al. 2010).

Hasil proses anodisasi yang dapat menghasilkan permukaan berpori dapat ditemukan pada berbagai penelitian. Pembentukan oksida logam di permukaan akan dilanjutkan dengan pembentukan pori dengan berbagai ukuran dan bentuk. Lapisan titanium oksida berpori dengan morfologi silindris dapat dibentuk dengan metode polarisasi dari material Ti-6Al-V (Karayan, Ferdian, dan Pratesa 2012). Hasil yang sama ditemukan pula pada material alumunium dengan pembentukan pori aluminum oksida di permukaan material (Rizkia et al. 2015). Selain itu, proses anodisasi ini lazim digunakan untuk memberikan efek warna pada material melalui poses electroless plating (Purnama dan Rizkia 2012) .

Usaha untuk membuat material yang bersifat tahan bakteri telah dilakukan dengan masukan partikel perak atau titanium oksida ke dalam porositas(Danookdharree et al. 2015; Besinis et al. 2017). Penelitian rekayasa permukaan aluminum menggunakan perak yang diendapkan di permukaan menggunakan arus bolak balik (AC) menunjukkan kemampuan membunuh bakteri hingga E.coli hingga 95\% (Chi et al. 2002). Namun, harga untuk pelapisan menggunakan perak akan mahal untuk aplikasi besar seperti kusen aluminium maupun gagang pintu.

Penelitian ini mencoba menggunakan metode sederhana dan material tembaga sebagai bahan pengganti perak yang mahal. Penelitian ini menawarkan metode alternatif dalam perlindungan korosi, sekaligus perlindungan antibakteri yaitu menggunakan tembaga. Penambahan lapisan tembaga sebagai penutup pori tidak banyak dilakukan oleh penelitian lain dibidang anodisisasi. Tembaga selain memberikan efek racun pada bakteri dan ketahanan korosi, akan memberikan efek warna kuning keemasan sehingga akan memberikan nilai estetika pada hasilnya.

Penelitian ini bertujuan untuk menciptakan lapisan tembaga yang masuk ke dalam pori dan mencegah pertumbuhan bakteri dalam pori seperti yang ditunjukan pada Gambar 1.

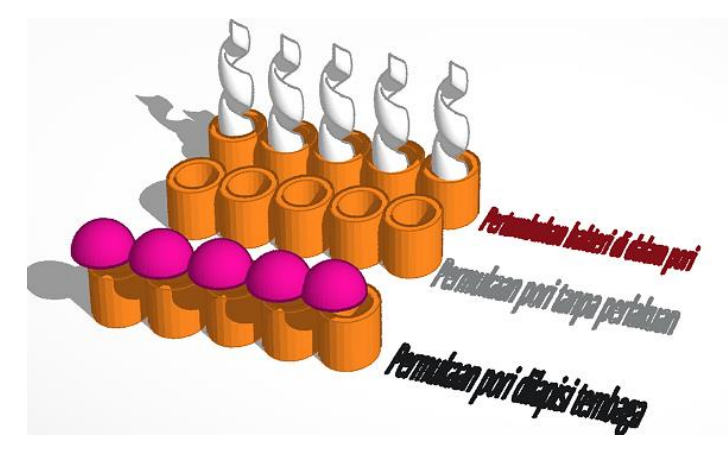

Gambar 1. Skema mekanisme antibakteri dari pelapisan tembaga pada material aluminium hasil anodisasi

\section{BAHAN DAN METODE}

\section{Bahan}

Aluminium 1xxx dengan diameter $3,5 \mathrm{~cm}$ dan tebal $0,5 \mathrm{~cm}$ yang telah dilakukan pengamplasan hingga grit 600 , direndam ke dalam larutan HF $5 \%$ selama 3 menit sampai 5 menit. Kemudian dilakukan anodisasi dengan larutan asam fosfat $\left(\mathrm{H}_{3} \mathrm{PO}_{4}\right) 5,19 \mathrm{M}$. Rangkaian sel elektrokimia tersusun dari kutub positif rectifier yang terhubung ke anoda (aluminium) dan kutub negatif rectifier yang terhubung ke katoda stainless steel.

Sampel di-anodisasi pada suhu $25{ }^{\circ} \mathrm{C}$ pada rapat arus $0,01 \mathrm{~A} / \mathrm{cm}^{2}$ selama 6 menit Selanjutnya dilakukan pembersihan dengan merendam sampel ke dalam gelas akuades selama 8 menit sampai 10 menit. Kemudian dilakukan pre-electroless coating selama 20 menit pada suhu $65{ }^{\circ} \mathrm{C}$ dalam larutan $\mathrm{N}_{2} \mathrm{H}_{4}$, $\mathrm{NH}_{4} \mathrm{OH}$ dan $\mathrm{CuSO}_{4}$ yang kemudian dilarutkan dalam air distilasi. Kemudian, dilakukan proses electroless coating dengan komposisi larutan yang sama dengan larutan pada pre-electroless coating, namun dilakukan pada suhu $83{ }^{\circ} \mathrm{C}$ 
dengan variasi waktu 13 menit, 26 menit, dan 39 menit. Variasi waktu ini dipilih menyesuaikan dengan studi yang telah dilakukan terlebih dahulu oleh (Seita et al. 2004). Pada penelitian tersebut menunjukan waktu perendaman terbaik untuk proses electroless plating adalah 13 menit (Seita et al. 2004). Variabel waktu yang dibahas pada penelitian ini dipillih karena ketahanan lapisan hasil electroless plating akan dipengaruhi oleh waktu dan lama pelapisan. Jika waktu pelapisan semakin lama, maka lapisan dapat menjadi merata, namun pada kondisi tertentu dapat lepas karena ketebalan yang terlampau besar akan memberikan tegangan tarik berlebih pada lapisan yang terbentuk.

\section{Metode}

Beberapa metode karakterisasi dilakukan untuk mengetahui sifat fisik, ketahanan korosi dan efek antibakteri pada bakteri E.coli. Uji metalografi dilakukan dilakukan menggunakan mikroskop optik dengan perbesaran 200, 500, dan 1000 pada penampang melintang untuk pengukuran ketebalan lapisan.

Pengujian antibakteri dilakukan menggunakan metode Kirby test dalam media agar Muller-Hinton $A(M H A)$ sebagai media perkembangbiakan bakteri Eschericia coli. Kemudian, cawan petri berisi media yang ditumbuhi bakteri tersebut diinkubasi pada temperatur $37{ }^{\circ} \mathrm{C}$ selama 26 jam. Uji Kirby ini dilakukan dengan meletakan sampel pada media agar yang telah ditumbuhi bakteri dan dilihat hasilnya setelah 26 jam. Hasil proses Kirby test ini dilihat dibawah mikroskop dan dihitung area bersih bakteri yang terbentuk.

Uji ketahanan korosi oleh lingkungan udara diwakili oleh uji sembur garam berdasarkan ASTM B117. Sampel-sampel diletakan di wadah sampel sembur garam untuk membentuk kemiringan sampel $45^{\circ}$ sampai $60^{\circ}$. Sampel dimasukan pada wadah sembur garam lalu larutan $\mathrm{NaCl} 5 \%$ yang terdapat pada wadah diubah menjadi kabut (fog) dengan tekanan 1 atm. Pengujian ini berdurasi selama 72 jam dan setelah selesai diamati dibawah mikroskop secara makro.

\section{HASIL DAN PEMBAHASAN}

\section{Mikrostruktur}

Pengujian mikroskop optik didapatkan dari mikrostruktur penampang melintang aluminium 1xxx setelah dilakukan proses electroless coating. Gambar 2 menunjukkan morfologi lapisan tembaga hasil proses pelapisan.

Hasil pengamatan mikrostruktur Gambar 2a pengamatan morfologi lapisan tembaga dengan waktu electroless plating 13 menit, terlihat pada permukaan aluminium dan belum terbentuk lapisan tembaga. Hal itu dapat dikarenakan waktu electroless plating belum mencukupi untuk membentuk suatu lapisan.

Pada Gambar 2b didapat morfologi lapisan tembaga dengan waktu electroless plating 26 menit, terlihat deposit tembaga yang lebih banyak pada permukaannya dan sudah membentuk lapisan yang cukup merata. Pada Gambar 2c didapat morfologi lapisan tembaga dengan waktu electroless plating 39 menit, terlihat terjadi pengurangan deposit tembaga pada permukaan aluminium.

Lapisan tembaga yang terbentuk terlihat memiliki celah diantara aluminium dengan lapisan tembaga. Celah yang terbentuk menandakan lapisan hasil electroless plating telah berikatan secara fisik dengan substrat logam. dengan demikian, kekasaran permukaan sangat berperan dalam kekuatan ikatan hasil pelapisan tersebut. Hal ini menjadi kekurangan yang umum pada lapisan hasil electroless plating. Umumnya celah yang terbentuk akan semakin besar pada hasil lapisan yang tebal, disebabkan karena semakin tebal lapisan yang terbentuk akan membuat lapisan terbentuk memiliki tegangan tarik sisa yang besar (Voorwald et al. 2007).

Jika melihat lebih jauh dari hasil pengamatan mikrostruktur terlihat bahwa lapisan tembaga lebih mudah terbentuk pada permukaan yang berbentuk celah. Kondisi ini telah dijelaskan oleh (Fromson 1977) yang mengemukakan bahwa pada permukaan yang berbentuk celah seperti hasil proses anodisasi, maka pada celah tersebut akan memiliki lapisan oksida aluminum $\left(\mathrm{Al}_{2} \mathrm{O}_{3}\right)$ yang lebih tipis, sehingga akan membuat logam lebih mudah untuk mengendap dan tumbuh dibagian tersebut (Fromson 1977).

Lapisan anodisasi berupa oksida alumunium merupakan insulator listrik yang buruk. Dalam hal ini, akan sulit bagi ion tembaga untuk menempel dan mengendap pada bagian oksida alumunium tersebut. Perbedaan ini membuat lapisan tembaga yang terbentuk tidak merata. Mekanisme ini diilustrasikan pada Gambar 3.

Gambar 4 menunjukkan pengurangan deposit tembaga seiring dengan penambahan waktu anodisasi. Kondisi tersebut disebabkan oleh ketebalan yang tinggi sehingga membuat lapisan tersebut terlepas kembali. Semakin tinggi ketebalan lapisan akan membuat perubahan beban tarik di lapisan yang terbentuk dan membuat menjadi rawan untuk terlepas (Nobari, Behboudnia, dan Maleki 2016).

Ketebalan lapisan berhubungan dengan ketahanan bakteri. Semakin tebal lapisan tembaga yang terbentuk maka air yang berasal dari uap air maupun cairan manusia yang menempel akan semakin sulit untuk 
berpenetrasi kepermukaan baja, hal ini membuat pertumbuhan bakteri akan semakin sulit.

Proses penempelan lapisan tembaga di permukaan material tidak melibatkan proses listrik seperti halnya proses elektrolisa. Namun pada metode ini, reaksi penempelan disebabkan adanya pertukaran elektron antara ion tembaga yang tereduksi dengan alumnium yang teroksidasi dengan reaksi reduksi dan oksidasi, seperti diperlihatkan oleh reaksi 1 dan 2 .

$$
\begin{aligned}
& \mathrm{Cu}^{2+}+2 \mathrm{e}^{-} \rightarrow \mathrm{Cu} \\
& \mathrm{Al} \rightarrow \mathrm{Al}^{3+}+3 \mathrm{e}^{-}
\end{aligned}
$$
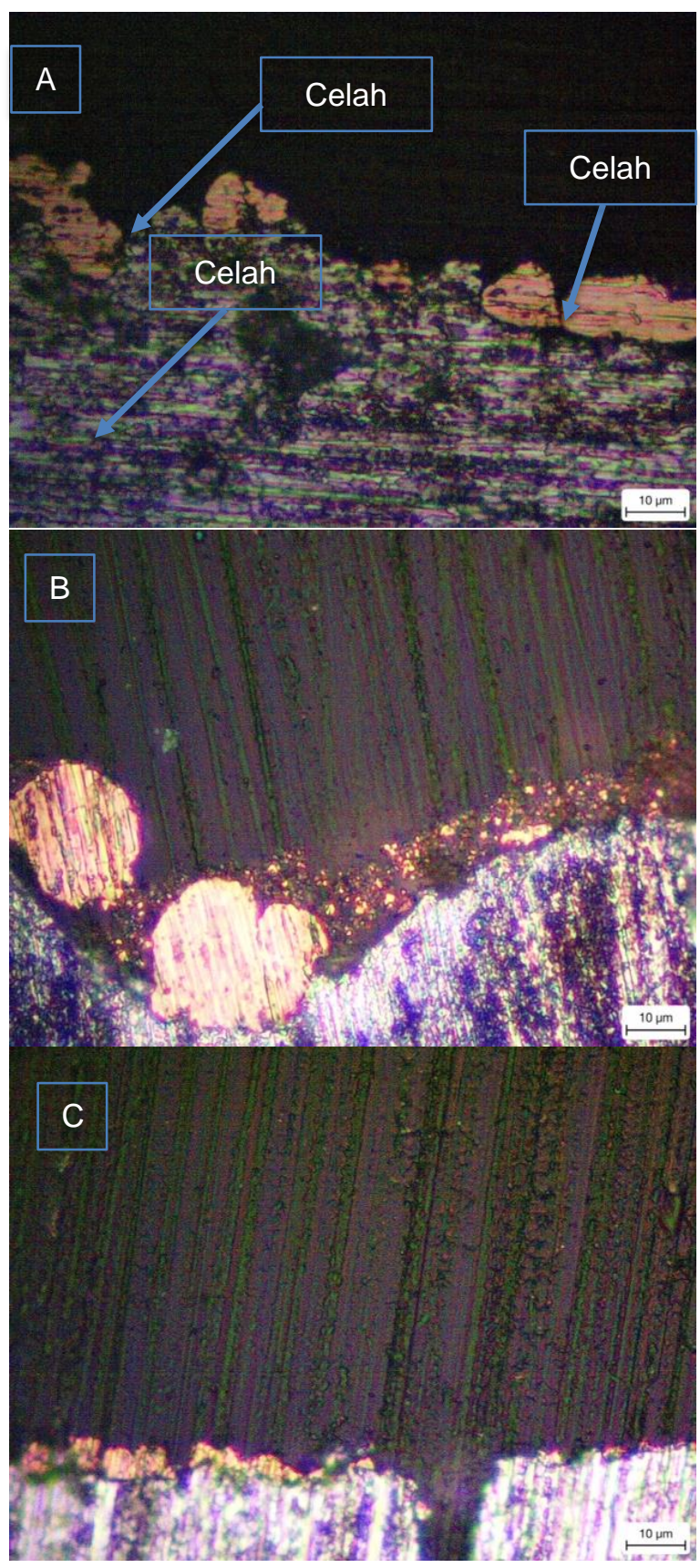

Gambar 2. Hasil electroless plating tembaga pada material alumunium hasil anodisasi selama (A) 13 (B) 26 dan (C) 39 menit terlihat ada celah yang masih terbentuk

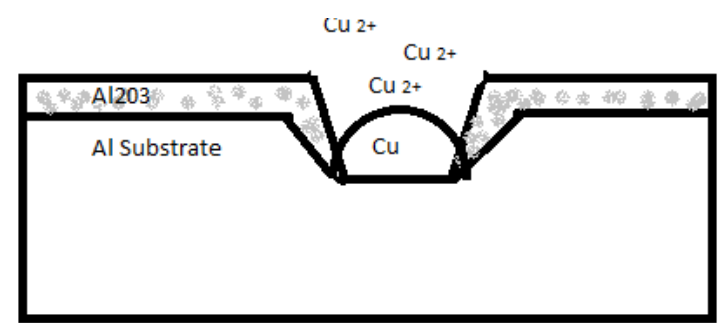

Gambar 3. Mekanisme pembentukan lapisan di celah

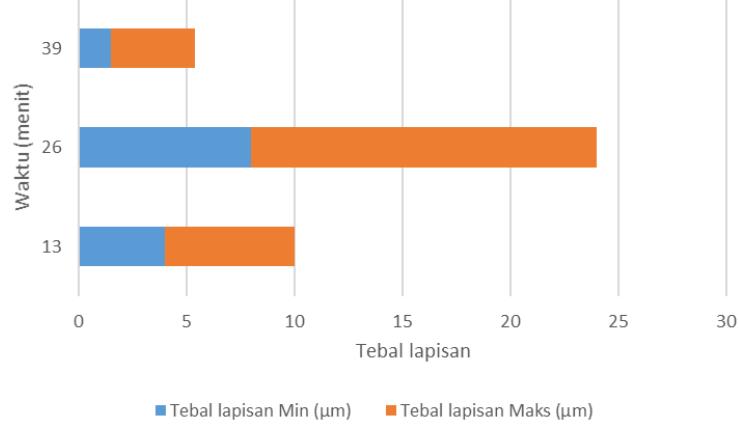

Gambar 4. Ketebalan hasil proses electroplating

Hasil pengujian mikrostruktur menunjukan bahwa dengan semakin rapat dan tebalnya lapisan tembaga yang terbentuk membuat bakteri akan semakin sulit menempel pada alumnium. Hal ini disebabkan ketika bakteri mencoba untuk menempel pada alumunium, bakteri harus melakukan kontak dengan tembaga dan tembaga akan terabsorp ke dalam membran bakteri dan membunuh bakteri tersebut.

\section{Antibakteri}

Pengujian antimikroba pada penelitian ini menggunakan metode Kirby-Bauer. Dari hasil pengujian tersebut terlihat bahwa lapisan tembaga pada aluminium dapat membuat logam tahan terhadap bakteri atau dengan kata lain bakteri tidak dapat tumbuh pada logam tersebut. Bukti dari hasil ini terlihat dari daerah berwarna kehitaman (daerah bersih) yang ada disekitar logam seperti terlihat pada Gambar 5.

Kondisi tersebut dapat terjadi karena ion $\mathrm{Cu}^{2+}$ pada lapisan tembaga menyerang lapisan sel luar dari bakteri dengan cara berikatan dengan gugus carbonyl dan kemudian dapat menghancurkan sel bakteri sehingga bakteri tidak dapat tumbuh disekitar lapisan tembaga tersebut (Pandiyarajan et al. 2013).

Gambar 5 merupakan logam pada agaragar Muller-Hinton A yang telah diberi bakteri Eschericia coli secara merata di dalam cawan petri tertutup. Gambar 5 menunjukkan adanya diameter yang bersih dari bakteri. Diameter yang bersih dari bakteri tersebut disebabkan oleh sifat antibakteri dari lapisan tembaga pada permukaan aluminium. 


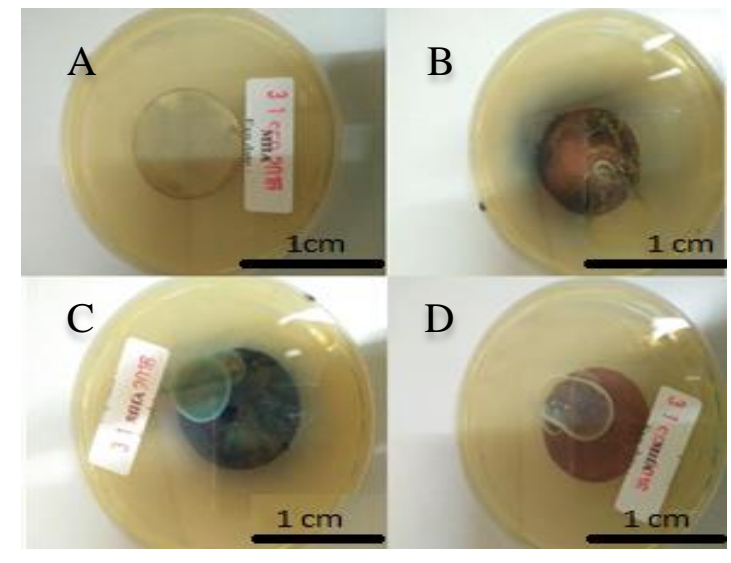

Gambar 5. Penampakan visual hasil Kirby Test dari sampel A) tanpa tembaga B) 13 menit C) 26 menit dan D) 39 menit

Diameter bersih yang lebih besar menunjukan resistansi logam terhadap bakteri yang diujikan semakin besar. Besar diameter hasil penelitian ini ditunjukkan pada Gambar 6 .

Pada Gambar 6, terlihat bahwa lapisan hasil electroless plating selama 26 menit dapat menghasilkan diameter paling besar. Kondisi ini menunjukan bahwa ketebalan dan kerataan hasil proses electroless plating berpengaruh terhadap sifat racun bakteri. Pada daerah yang tidak tertutup oleh lapisan tembaga akan ditembus oleh bakteri sehingga ketebalan daerah bersihnya lebih tipis.

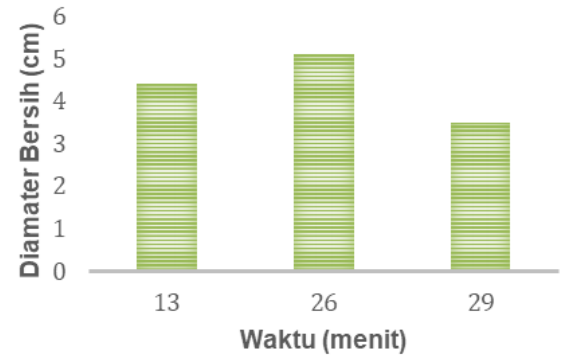

Gambar 6. Ukuran area bersih hasil Kirby test

\section{Ketahanan Korosi Atmospherik}

Uji sembur garam (salt spray test) merupakan metode pengujian untuk mengetahui ketahanan suatu lapisan protektif terhadap lingkungan atau korosi. Jika ketebalan lapisan pada material merata maka lapisan tersebut akan baik dalam memberikan perlindungan terhadap lingkungan atau korosi. Sementara jika ketebalan lapisan tidak merata atau terdapat lapisan yang tipis dibandingkan yang lain, lapisan yang tipis tersebut akan lebih mudah untuk terkorosi dibandingkan dengan lapisan yang tebal. Ciri khas dari rusaknya lapisan tembaga adalah perubahan warna tembaga menjadi warna hitam yang merupakan ciri khas dari tembaga oksida ( $\mathrm{CuO}$ ) yang merupakan hasil proses oksidasi tembaga oleh oksigen melalui reaksi pada Persamaan (3) sampai dengan Persamaan (6).

Tembaga seharusnnya logam yang lebih katodik dibandingkan dengan alumunium, sehingga jika tembaga berdekatan dengan alumunium, reaksi galvanis akan terjadi antara keduanya, dimana alumunium akan terkorosi (Charles Forman dan Verchot 1967). Namun pada kasus ini terlihat bahwa tembaga mengalami hal yang sama.

Kerusakan lapisan tembaga tersebut dapat dijelaskan dimulai dengan reaksi antara alumunium dan asam klorida. Alumunium yang tidak tertutup oleh tembaga akan bereaksi dengan uap garam membentuk Alumunium hidroksida klorida dan kemudian berubah menjadi alumunium klorida $\left(\mathrm{AlCl}_{3}\right)$. Asam klorida terbentuk akibat reaksi antara alumunium klorida $\left(\mathrm{AlCl}_{3}\right)$ dengan air seperti ditunjukan pada reaksi 3 dan 4.

$$
\begin{aligned}
& \mathrm{Al}(\mathrm{OH}) \mathrm{Cl}_{2}+\mathrm{Cl}^{-} \rightarrow \mathrm{AlCl}_{3}+\mathrm{OH}^{-} \\
& \mathrm{AlCl}_{3}+3 \mathrm{H}_{2} \mathrm{O} \rightarrow \mathrm{Al}(\mathrm{OH})_{3}+\mathrm{HCl}
\end{aligned}
$$

yang terbentuk kemudian menyerang tembaga merubahnya menjadi $\mathrm{CuCl}_{2}$ yang kemudian bereaksi dengan oksida membentuk $\mathrm{O}_{2}$ seperti diperlihatkan pada reaksi 5 dan 6

$$
\begin{gathered}
\mathrm{Cu}+\mathrm{HCl} \rightarrow \mathrm{CuCl}_{2} \\
2 \mathrm{CuCl}_{2}+\mathrm{O}_{2} \leftrightarrow 2 \mathrm{CuO}+2 \mathrm{Cl}_{2}
\end{gathered}
$$

Hasil uji sembur garam menunjukan bahwa kerusakan yang paling parah adalah pada sampel anodisiasi dengan lama proses electroless plating selama 39 menit seperti diperlihatkan pada Gambar 7. Kondisi tersebut ditandai dengan perubahan warna tembaga menjadi warna hitam sebagai ciri khas dari oksida tembaga (CuO). Kondisi ini terjadi karena lapisan tembaga pada proses pelapisan selama 39 menit lebih tipis dibandingkan hasil variable waktu pelapisan lainnya. Sedangkan pada hasil pelapisan selama 26 menit, warna lapisan tembaga tidak berubah.

Lapisan putih yang terlihat setelah proses uji salt spray merupakan karat dari aluminium. Alumunium yang teroksidasi oleh air garam akan membuat lapisan putih oksida aluminium yang terdiri atas $\mathrm{Al}_{2} \mathrm{O}_{3}$. Oksida alumunium ini terbentuk dari reaksi oksidasi bertahap. Tahap pertama adalah pembentukan alumunium klorida $\left(\mathrm{AlCl}_{3}\right)$. $\mathrm{AlCl}_{3}$ lebih jauh akan bereaksi kembali dengan uap air $\left(\mathrm{H}_{2} \mathrm{O}\right)$ dan menghasilkan asam klorida yang agresif menyerang lapisan pasif aluminium oksida $\left(\mathrm{Al}_{2} \mathrm{O}_{3}\right)$ dan tembaga $(\mathrm{Cu})$. 


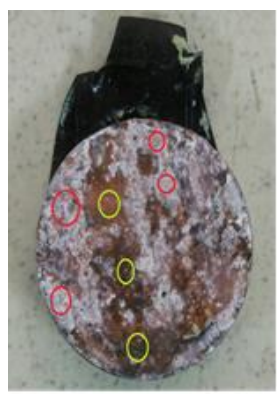

13 menit

Lapisan garam

Sisa lapisan tembaga

Gambar 7. Penampakan visual hasil uji sembur garam

\section{KESIMPULAN}

Lapisan tembaga hasil proses electroless plating bekerja dengan baik mencegah pertumbuhan bakteri di permukaan aluminum hasil anodisasi. Lapisan paling optimal terbentuk setelah proses electroless plating selama 26 Menit. Hasil pengujian metalografi menunjukan ketebalan lapisan yang dihasilkan maksimal sebesar $24 \mu \mathrm{m}$. Meskipun demikian, kemampuan antibakteri yang diberikan pelapisan tembaga tetap terjadi di berbagai variasi waktu electroless plating.

\section{UCAPAN TERIMAKASIH}

Penulis mengucapkan terimakasih sebesarbesarnya atas dana kegiatan Penelitian Kreativitas Mahasiswa (PKM) 2015 dari Tanoto Foundation.

\section{DAFTAR PUSTAKA}

Arnold, J.W., dan G.W. Bailey. 2000. "Surface finishes on stainless steel reduce bacterial attachment and early biofilm formation: scanning electron and atomic force microscopy study." Poultry Science 79 (12): 1839-45. doi:10.1093/ps/79.12.1839.

Aykent, F., I. Yondem, A.G. Ozyesil, S.K. Gunal, M.C. Avunduk, dan S. Ozkan. 2010. "Effect of different finishing techniques for restorative materials on surface roughness and bacterial adhesion." The Journal of Prosthetic Dentistry 103 (4): 221-27. doi:https://doi.org/10.1016/S00223913(10)60034-0.

Besinis, A., S.D. Hadi, H.R. Le, C. Tredwin, dan R.D. Handy. 2017. "Antibacterial activity and biofilm inhibition by surface modified titanium alloy medical implants following application of silver, titanium dioxide and hydroxyapatite nanocoatings." Nanotoxicology 11 (3). Taylor \& Francis: 327-38. doi:10.1080/17435390.2017.1299890.

Charles Forman, M., dan A.E. Verchot. 1967. "Practical galvanic series." Alabama.

Chi, G.J., S.W. Yao, J. Fan, W.G. Zhang, dan H .Z. Wang. 2002. "Antibacterial activity of anodized aluminum with deposited silver." Surface and Coatings Technology 157 (2): 162-65. doi:https://doi.org/10.1016/S02578972(02)00150-0.

Danookdharree, U., H. Le, R. Handy, dan C. Tredwin. 2015. "Antibacterial coating made of strongly adhered nanosilver to titania nanotubes for dental implants." In Proceedings of the British Society for Oral and Dental Research (BSODR) Annual Meeting.

Fromson, H.A. 1977. Process of Making Electroplated Anodized Aluminum articles and Electroless Plating. 4,021,592, issued 1977.

Karayan, A.I., D. Ferdian, dan Y. Pratesa. 2012. "Synthesis of TiO2 nanotube on Ti-10Ta$10 \mathrm{Nb}$ thin film by anodization." International Journal of Technology 3 (2): 140-44.

Nobari, N., M. Behboudnia, dan R. Maleki. 2016. "Palladium-free electroless deposition of pure copper film on glass substrate using hydrazine as reducing agent." Applied Surface Science 385: 9-17. doi:https://doi.org/10.1016/j.apsusc.2016.0 5.033 .

Pandiyarajan, T., R. Udayabhaskar, S. Vignesh, R.A. James, dan B. Karthikeyan. 2013. "Synthesis and concentration dependent antibacterial activities of $\mathrm{CuO}$ nanoflakes." Materials Science and Engineering: C 33 (4): $\quad 2020-24$. doi:https://doi.org/10.1016/j.msec.2013.01. 021.

Purnama, D., dan V. Rizkia. 2012. "Pelapisan aluminium dengan proses anodisasi multiwarna untuk aplikasi" 11 (3).

Rizkia, V., B. Munir, J.W. Soedarsono, dan B. Suharno. 2015. "Corrosion resistance enhancement of an anodic layer on an aluminum matrix composite by cerium sealing." International Journal of Technology 7: 1191-97.

Seita, M., H. Tsuchida, M. Imanari, Y. Sugita, A. Egli, dan W. Brasch. 2004. Formaldehydefree electroless copper platingprocess and solution for use in the process. US $20040253450 A 1$, issued 2004.

Voorwald, H.J.C., R.Q. Padilha, L.W. Pigatin, M.O.H. Cioffi, dan M.P. Silva. 2007. "Influence of electroless nickel interlayer thickness on fatigue strength of chromiumplated AISI 4340 steel." ESIS -ECF 15 Sweden, 895-704. 